\title{
Prevalence of Bovine Immunodeficiency Virus Infection in Buffaloes in East Azerbaijan, Northwestern Iran
}

\author{
Mohammad Tolouei-Kaleibar ${ }^{1,{ }^{*}}$, Morteza Mozaffari ${ }^{2}$, Javad Ashrafi ${ }^{3}$, Golamreza Nikbakht ${ }^{4}$ \\ and Ezzatollah Fathi ${ }^{5}$
}

${ }^{1}$ Large Animal Internal Medicine, Faculty of Veterinary Medicine, University of Tabriz, Tabriz, Iran

${ }^{2}$ Large Animal Internal Medicine, Faculty of Veterinary Medicine, University of Tehran, Tehran, Iran

${ }^{3}$ Veterinary Pathology, Faculty of Veterinary Medicine, University of Tabriz, Tabriz, Iran

${ }^{4}$ Veterinary Virology, Faculty of Veterinary Medicine, University of Tehran, Tehran, Iran

${ }^{5}$ Veterinary Clinical Pathology, Faculty of Veterinary Medicine, University of Tabriz, Tabriz, Iran

\begin{abstract}
Bovine immunodeficiency virus (BIV) has a worldwide distribution, but its prevalence in different regions of Iran is unknown. In this study, for the first time, the presence of BIV infections is detected by using the PCR method in Iranian water buffalo in East Azerbaijan. For this matter, blood samples were taken from 83 randomly selected buffaloes slaughtered in Tabriz industrial slaughterhouse from June to October 2012. All of the animals were clinically examined before sampling. Viral Gene-spin ${ }^{\mathrm{TM}}$ Viral DNA/RNA Extraction Kit was used to extract the DNA, and PCR was performed on the extracted DNA using oligonucleotiode primers specific for the gag gene region of the BIV virus. The prevalence of BIV in buffaloes was $2.4 \%$ (2 of 83 ), which is less than the prevalence of BIV in Pakistan (10.3\%) and India (19\%). The low prevalence observed in this study may be due to our small sample size.
\end{abstract}

Keywords: Bovine immunodeficiency virus, PCR, Buffalo, Iran.

\section{INTRODUCTION}

Bovine immunodeficiency virus (BIV) is a lentivirus. Lentiviruses are a widely disseminated group of exogenous non-oncogenic retroviruses, which include visna-maedi virus of sheep, equine infectious anaemia virus (EIAV), caprine arthritis encephalitis virus (CAEV), bovine immunodeficiency virus (BIV), feline immunodeficiency virus (FIV) and jembrana disease virus (JDV). These viruses are genetically related and share certain biologic and pathogenic characteristics [1]. There is also cross-reactivity between antigens of different lentiviruses [2, 3]. BIV is also closely related to the human immunodeficiency virus type 1 (HIV-1) [4, 5].

BIV was originally isolated from an 8-year-old dairy cow with persistent lymphocytosis, progressive weakness and wasting and was appointed in 1972 as R29 [6]. After BIV's recognition as a lentivirus in the late 1980s, it has been shown that the BIV infections occur widely, causing lifelong and generally subclinical diseases [7].

BIV infections have been shown to be variably associated with alterations in animal production, weight loss, secondary diseases, decreased milk production

*Address correspondence to this author at the Large Animal Internal Medicine, Faculty of Veterinary Medicine, University of Tabriz, Tabriz, Iran;

Tel: 09141080928; E-mail: Mtooloei@tabrizu.ac.ir

ISSN: 1927-5196 / E-ISSN: 1927-520X/18 and increased incidence of encephalitis [8-10]. Whether BIV transmission via uterus, placenta, colostrum, or milk is still under investigation but Proviral DNA of BIV was also detected in bull semen [11, 12]. and it has been shown that the seroprevalence of BIV infection increases according to the aging of animals in the same dairy herd, suggesting that BIV would be possibly transmitted through natural or artificial inseminations, and/or through blood instrument or blood sucking insects [13-15]. Although BIV induces dysfunction in monocytes and neutrophils, BIV inoculated calves did not exhibit severe clinical symptoms, so pathogenesis of BIV remains unclear [16-18]. The clinical significance of BIV infection can depend on the strain of BIV, breed of the cattle, and environmental stressors [19].

Buffalo is a native animal of Iran and East Azerbaijan province, with a total population of about 92620 , is one of the most important regions of buffalo farming. As there is no data on BIV in Iranian buffaloes, we conducted the prevalence of this infection in Azerbaijan.

\section{MATERIALS AND METHODS}

\section{Blood Sampling}

A total of 83 whole peripheral blood samples were collected from randomly selected Asian water buffalos 
(Bubalus bubalis) slaughtered in Tabriz industrial slaughtered house in East Azerbaijan province of Iran from June to October 2012. (31 animals were female and the others were male and the all of them had more than 3-year-old age.) Ethylenediaminetetraacetic acid (EDTA) was used in sampling tubes as an anticoagulant agent.

For the preparation of DNA, aliquots of whole blood $(500 \mu \mathrm{l})$ were added to $1 \mathrm{ml}$ red blood cell lysis buffer (10 mM Tris- $\mathrm{HCl} \mathrm{pH} 7.6 ; 5 \mathrm{mM} \mathrm{MgCl}_{2}, 100 \mathrm{mM} \mathrm{NaCl}$, $0.75 \%$ Triton X-100) and were mixed and incubated at room temperature for 2 minutes. The tubes were then centrifuged at $12000 \mathrm{~g}$ for 20 seconds and the supernatant was discarded. The pellets were frozen at $-70^{\circ} \mathrm{C}$ until they were examined.

\section{DNA Extraction}

For DNA extraction, Viral Gene-spin ${ }^{\mathrm{TM}}$ Viral DNA/RNA Extraction Kit (Intron Biotechnology.Inc) was used.

At first, the pellet was transferred to the $1.5 \mathrm{ml}$ micro-centrifuge tube, resuspended in $250 \mu \mathrm{l}$ Viral Gene-spin ${ }^{\mathrm{TM}}$ buffer (Lysis buffer) and incubated at $80^{\circ} \mathrm{C}$ for $10 \mathrm{~min}$. After that, it was mixed by vortexing for 15 seconds and incubated at room temperature (15$25^{\circ} \mathrm{C}$ ) for $10 \mathrm{~min}$, then $350 \mu \mathrm{l}$ of binding buffer added and completely mixed by gently vortexing, subsequently the solution was placed in a spin column in a provided $2 \mathrm{ml}$ collection tube and centrifuged at $13,000 \mathrm{rpm}$ for $1 \mathrm{~min}$. The solution in collection tube was discarded and the column was placed back in the same $2 \mathrm{ml}$ collection tube, afterwards, $500 \mu \mathrm{l}$ of Washing Buffer $A$ was added to the column and centrifuged for 1 min at 13000 rpm, the solution in collection tube was discarded and placed the spin column back in the same $2 \mathrm{ml}$ collection tube. Then $500 \mu \mathrm{l}$ of Washing Buffer $\mathrm{B}$ was added to the column and centrifuged for
$1 \mathrm{~min}$ at $13000 \mathrm{rpm}$. The solution in collection tube was discarded and the spin column was placed back in the same $2 \mathrm{ml}$ collection tube, subsequently centrifuged for $1 \mathrm{~min}$ at $13000 \mathrm{rpm}$. Then the column was placed in an RNase-free $1.5 \mathrm{ml}$ micro-centrifuge tube, $60 \mu \mathrm{l}$ of Elution buffer was added directly onto the membrane and was incubated at room temperature for $1 \mathrm{~min}$, then was centrifuged for $1 \mathrm{~min}$ at 13000rpm. 2-5 $\mu \mathrm{l}$ of an eluted solution was used as a template for PCR.

\section{Polymerase Chain Reaction}

The DNA extracted from each blood sample was used as a template to detect BIV proviral DNA by PCR as described previously by Nikbakht et al. (2010) [20]. The primers chosen are listed in Table 1.

A $25 \mathrm{ml} \mathrm{PCR}$ reaction mix contained $0.5 \mu \mathrm{l}$ of each primer, $0.2 \mu \mathrm{l}$ of dNTP, $0.5 \mu \mathrm{l}$ Taq DNA polymerase, $1 \mu \mathrm{MgCl}_{2}$ (concentration fixed by titration tests), 2.5 reaction buffer, and $16 \mu \mathrm{l}$ D.D. water. Two $\mathrm{ml}$ of DNA template were obtained from all samples. The PCR was performed for 37 cycles in three stages: 1 cycle $\left(94^{\circ} \mathrm{C}\right.$ for $1 \mathrm{~min}, 51^{\circ} \mathrm{C}$ for 45 second, $72^{\circ} \mathrm{C}$ for $1 \mathrm{~min}$ ), 35 cycles $\left(94^{\circ} \mathrm{C}\right.$ for 45 second, $51^{\circ} \mathrm{C}$ for 30 second, $72^{\circ} \mathrm{C}$ for 45 second) and 1 cycle $\left(72^{\circ} \mathrm{C}\right.$ for $\left.5 \mathrm{~min}\right) .7 \mu \mathrm{l}$ of each reaction mixture was mixed with $2 \mu l$ of loading buffer and run on a $1.2 \%$ agarose then stained by ethidium bromide and visualized by a U.V. transilluminator. $750 \mathrm{bp}$ DNA marker was used to distinguish DNA fragment bands in lanes. Plasmid DNA containing the complete BIV gag-coding region (pGEM7-gag) served as a positive control and water was used as a negative control.

\section{RESULTS}

Of the 83 DNA samples from buffalo's blood, 2 specimens $(2.4 \%)$ contained 393bp DNA fragment bands (Table 2).

Table 1: Nucleotide Sequences and Positions of Primers Used for Amplification of gag Fragment of Bovine Immunodeficiency Virus

\begin{tabular}{|c|c|c|c|c|}
\hline bp & Sequence & Genomic position & gen & Primer \\
\hline \multirow{2}{*}{393} & $5^{\prime}$ - AGATCTGGTCAGACGCCA- 3' & $821-838$ & gag & NIK BIV F \\
\hline & 5'- CTGTGTACGGCTCCTTGG- $3^{\prime}$ & $1196-1213$ & gag & NIK BIV R \\
\hline
\end{tabular}

Table 2: Prevalence of BIV Buffaloes in East Azerbaijan

\begin{tabular}{|c|c|c|c|}
\hline Species & Samples & Positive samples \\
\hline \hline Buffalo & 83 & 2 & $2.4 \%$ \\
\hline
\end{tabular}




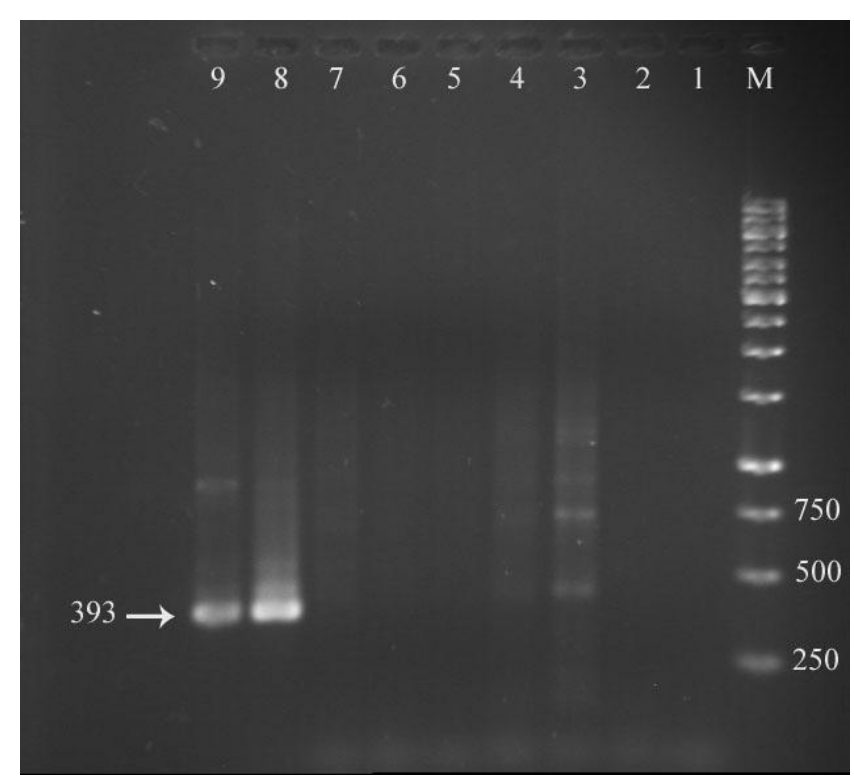

Figure 1: Ethidium bromide-stained agarose gel of PCR products amplified with BIV gag primers. DNA I, 000 bp markers (lane M), negative control (lane 1), positive control (lane 9), DNA samples from Buffaloes (lane 2-8). Sample 3 and 8 are positive.

\section{DISCUSSION}

BIV is prevalent globally. The earliest report of the incidence of BIV in Louisiana cattle indicated a collective seroprevalence of $11 \%$ in four dairy herds [21] and in 1992 seroprevalence of BIV in beef herds and dairy herds of Louisiana was reported $40 \%$ and $60 \%$, respectively [22].

In 1992 BIV seroprevalence was reported $21 \%$ in a dairy herd of Colorado [23] and one study in Italy demonstrated that $5.8 \%$ of the dairy herds and $2.5 \%$ of the tested cows were seropositive for BIV [24]. A seroepidemiological investigation of BIV infection in two Mississippi dairy herds revealed $38-58 \%$ incidence of BIV infection in [15]. In Canada Gonzalez et al. utilized a simple gene amplification technique for detection of sequences from the 3 major BIV genes, gag, pol and env. and indicated that, the frequency of BIV infection is $5.5-12 \%$ among dairy cattle in Ontario [17]. A study in Argentina showed that $12 \%$ of the animals tested were positive for BIV [25]. In 1998 a study using western blot method revealed that $11.7 \%$ of the cattle in Hokkaido had the antibodies against BIV [14]. In another study by Meas et al. (2000) [26] performed in 5 states in Cambodia, 544 cattle and 42 buffalos were examined. This research indicated that $26.3 \%$ of the cattle and $16.7 \%$ of the buffalos were positive for antiBIV-P26 antibodies. In another survey that was performed on buffaloes in Pakistan by using recombinant nested PCR assay to detect proviral DNA,
$10.3 \%$ of buffalos and $15.8 \%$ of cattle were seropositive [11]. In a study in Zambia, $11.4 \%$ out of a total of 262 sera were found positive for anti-BIV p26 antibodies [27]. In Korea, $35 \%$ and $33 \%$ of dairy and beef cattle were BIV seropositive, respectively [13]. A serological and molecular study showed that $12.3 \%$ of cattle were infected with BIV in Turkey [18]. A study in India showed that $22 \%$ of cattle and $19 \%$ of buffalos were seropositive [28]. In Poland, 1541 serum samples from Holstein cattle from 23 herds were analyzed using ELISA method. The average BIV prevalence was $4.9 \%$ in individual cattle while the percentage of herds harboring at least one seropositive animal, was $82.6 \%$ [29].

Investigation on BIV in Iran revealed $20.3 \%$ of positive cattle in Tehran province [20], $60 \%$ and $30 \%$ of positive cattle and sheep in Chaharmahal Bakhtiary province of Iran [30].

To the best of our knowledge, this is the first report of BIV infection in Iranian water buffalo.

The prevalence of BIV in buffaloes in this study was lower than the prevalence of BIV observed in Pakistan $(10.3 \%)$ and India (19\%). However, this result may be due to the small sample size. Our study adds to the available data on BIV and is the first report of this disease in buffaloes in Iran. Further studies are needed to determine the epidemiology of the infections in Iran.

\section{ACKNOWLEDGEMENTS}

We sincerely thank the Talent Guidance Office of Tabriz University for funding this study.

\section{REFERENCES}

[1] Gifford RJ, Katzourakis A, Tristem M, Pybus OG, Winters M Shafer RW. A transitional endogenous lentivirus from the genome of a basal primate and implications for lentivirus evolution. Proc Natl Acad Sci USA 2008; 105: 20362-67. https://doi.org/10.1073/pnas.0807873105

[2] Horzinek M, Keldermans L, Stuurman T, Black J, Herrewegh A, Sillekens $P$, Koolen M. Bovine immunodeficiency virus: immunochemical characterization and serological survey. J Gen Virol 1991; 72: 2923-2928. https://doi.org/10.1099/0022-1317-72-12-2923

[3] ST-Louis MC, Cojocariu M, Archambaut D. The molecular biology of bovine immunodeficiency virus: a comparison with other lentiviruses. Anim Health Res Rev 2004; 5: 125-143. https://doi.org/10.1079/AHR200496

[4] Garvey KJ, Oberste MS, Elser JE, Braun MJ, Gonda MA. Nucleotide sequence and genome organization of biologically active proviruses of the bovine immunodeficiency-like virus. Virology 1990; 175: 391-409. https://doi.org/10.1016/0042-6822(90)90424-P

[5] Gonda MA, Braun MJ, Carter SG, Kost TA, Bess JW, Arthur LO, Van Der Maaten MJ. Characterization and molecular 
cloning of a bovine lentivirus related to human immunodeficiency virus. Nature 1987; 330: 388-391. https://doi.org/10.1038/330388a0

[6] Van der Maaten MJ, Boothe AD, Seger CL. Isolation of a virus from cattle with persistent lymphocytosis. J Natl Cancer Inst 1972; 49: 1649-1657. https://doi.org/10.1093/jnci/49.6.1649

[7] Bruce WM, Robert MJ, Helen ES. A Serological Survey for Bovine Immunodeficiency-like Virus in Ontario Dairy Cattle and Associations between Test Results,Production Records and Management Practices. Can J Vet Res 1994; 58: 36-41.

[8] Flaming et al., 1993.

[9] Gradil et al., 1999.

[10] Tajima et al., 1997.

[11] Meas S, Ohashi K, Tum S, Chhin M, Kuhor Te, Miura K, Sugimoto C, Onuma M. Seproprevalence of Bovine immunodeficiency virus and Bovine leukemia virus in Draught animals in Cambodia. J Vet Med Sci 2000; 62: 779781.

https://doi.org/10.1292/jvms.62.779

[12] Nash JW, Hanson LA, St. Cyt Coat K. Bovine Immunodeficiency virus in stud bull semen. Am J Vet Res 1995; 6: 760-763.

[13] Cho KO, Meas S, Park NY, Kim YH, Lim YK, Endoh D, Lee SI, Ohashi K, Sugimoto C, Onuma M. Seroprevalence of bovine immunodeficiency virus in dairy and beef cattle herds in Korea. J Vet Med Sci 1999; 61: 549-551. https://doi.org/10.1292/jvms.61.549

[14] Meas S, Kabeya H, Yoshihara S, Ohashi K, Matsuski S, Mikami Y, Sugimoto C, Onurma M. Seroprevalence and field Isolation of Bovine immunodeficiency virus. J Vet Med Sci 1998; 60: 1195-2002. https://doi.org/10.1292/jvms.60.1195

[15] St-Cyr Coats K, Pruett SB, Nash JW, Cooper CR. Bovine immunodeficiency virus: incidence of infection in Mississippi cattle. Vet Microbiol 1994; 42: 181-189. https://doi.org/10.1016/0378-1135(94)90017-5

[16] Carpenter S, Vaughn EM, Yang J, Baccam P, Roth JA, Wannemuhler $Y$. Antigenic and genetic stability of bovine immunodeficiency virus during long-term persistence in cattle experimentally infectied with the BIV R29, isolate. J Gen Virol 2000; 81: 1463-1472.

https://doi.org/10.1099/0022-1317-81-6-1463

[17] Gonzalez GC, Johnston JB, Nickel DD, Jacobs RM, Olson M, Power C. Very low prevalence of Bovine Immunodeficiency virus infection in western Canadian cattle. Can J Vet Res 2000; 65: 73-76

[18] Yilmaz Z, Yesilbag K. Clinical and Hematological findings in bovine immunodeficiency virus (BIV) Infected cattle. Turk J Vet Anim Sci 2008; 32: 207-214.

[19] Belloc C, Polack B, Schwartz-Cornil I, Brownlie J, Levy D. Bovine immunodeficiency virus: facts and questions. Vet Res 1996; 27: 395-402.

[20] Nikbakht Brujeni G, Taghi Poorbazargani T, Nadin-Davis S, Tolooie M, Barjesteh N. Bovine immunodeficiency virus and bovine leukemia virus and their mixed infection in Iranian Holstein cattle. J Infect Dev Ctries 2010; 4(9): 576-579. https://doi.org/10.3855/jidc.711

[21] Amborski GF, Lo JL, Seger CL. Serological detection of multiple retroviral infections in cattle: bovine leukemia virus, bovine syncytical virus and bovine visna virus. Vet Microbiol 1989; 20: 247-253. https://doi.org/10.1016/0378-1135(89)90048-5

[22] Gonda MA, Luther DG, Fong SE, Tobin GJ. Bovine immunodeficiency virus: Molecular biology and virus-host interactions. Virus Research 1994; 32: 155-181. https://doi.org/10.1016/0168-1702(94)90040-X

[23] Cockerell GI, Jensen WA, Rovnak J, Ennis WH, Gonda MA. Seroprevalence of Bovine immunodeficiency-Like virus and bovine leukemia virus in a dairy cattle herd. Vet Mircrobiol 1992; 31: 109-116. https://doi.org/10.1016/0378-1135(92)90069-6

[24] Cavirani S, Donofrio G, Chiocco D, Foni E, Martelli P, Allegri G, Cabassi CS, De IB, Flammini CF. Seroprevalence to bovine immunodeficiency virus and lack of association with leukocyte counts in Italian dairy cattle. Prev Vet Med 1998; 37: 147-157. https://doi.org/10.1016/S0167-5877(98)00099-3

[25] Gonzalez ET, Licursi M, Vila Roza V, Bonzo E, Mortola E, Frossard JP, Venables C. Evidence of bovine immunodeficiency virus (BIV) infection: Serological survey in Argentina. Res Vet Sci 2008; 85: 353-358. https://doi.org/10.1016/j.rvsc.2007.10.008

[26] Meas S, Seto J, Sugimoto C, Bakhsh M, Riaz M, Sato T, Naeem K, Ohashi K, Onuma M. Infection of bovine immunodeficiency virus and bovine leukemia virus in water buffalo and cattle populations in Pakistan. J Vet Med Sci 2000; 62: 329-331. https://doi.org/10.1292/jvms.62.329

[27] Meas S, Nakayama M, Usui T, Nakazato Y, Yasuda J, Ohashi K, Onuma M. Evidence for Bovine immunodeficency virus Infection in cattle in Zambia. Jpn J Vet Res 2004; 52: 38.

[28] Bhatia S, Sood R, Bhatia AK, Pattnaik B, Pradhan HK. Development of a capsid based competitive inhibition enzyme-linked immunosorbent assay for detection of bovine immunodeficiency virus antibodies in cattle and buffalo serum. Journal of Virological Methods 2008; 148: 218-225. https://doi.org/10.1016/j.jviromet.2007.11.008

[29] Rola-Luszczak M, Kozaczynska B, Kuzmak J. Serological survey for bovine immunodeficiency virus in dairy cattle from Poland. Polish Journal of Veterinary Sciences 2011; 14(4): 579-583. https://doi.org/10.2478/v10181-011-0086-8

[30] Tajbakhsh E, Nikbakht Borujeni G, Momtaz H. Molecular evidence for bovine immunodeficiency virus infection in Iranian sheep and cattle population. Comp Clin Pathol 2011; 20: $635-638$.

https://doi.org/10.1007/s00580-010-1048-8 